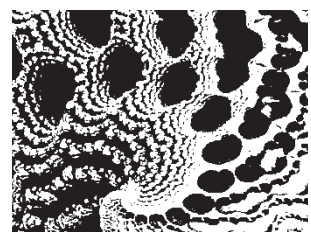

\title{
COPING AND EMOTION REGULATION STRATEGIES IN ADULTHOOD: SPECIFICITIES REGARDING AGE, GENDER AND LEVEL OF EDUCATION
}

Helena SMRTNIK VITULIĆ and Simona PROSEN Faculty of Education, Ljubliana

UDK: 159.942.4-053.8-057.8:305

Izvorni znanstveni rad

Primljeno: 29. 9. 2015.

In the study, the use of coping and emotion regulation (ER) strategies is compared in 194 adults aged between 20 and 65 years, regarding their age (emerging, young or middle adulthood), gender and level of education. There are almost no significant differences in the use of coping and ER strategies in adults regarding age. Women use certain ER strategies (e.g., attentional deployment) more than men, but there is no difference between the two groups in the use of coping strategies. Adults with a low level of education use more confrontive coping and distracting in comparison with adults with a high level of education, while the escape-avoiding coping strategy is used more by adults with low and middle levels of education than those with a high level of education. Regarding ER, adults with a low level of education use more cognitive reappraisal of importance than both groups with a higher educational level, whereas they use suppression and substances only more than adults with a high level of education. Correlations between coping and ER strategies are mostly non-significant, suggesting that coping and ER are distinct processes in adulthood.

Keywords: coping, emotion regulation, adulthood, gender differences, education level

$\triangle \quad$ Helena Smrtnik Vitulić, University of Ljubljana, Faculty of Education, Kardeljeva ploščad 16, 1000 Ljubljana, Slovenia. 
Learning how to cope with stressful events and how to regulate one's emotions are among the core aspects of development from childhood to adulthood (Compas et al., 2014), as these skills play an important role in overall adaptational outcomes (Bonanno \& Burton, 2013). Coping and emotion regulation (ER) have a significant impact on the individual's normative or risk development, especially on physical (e.g. Folkman, Lazarus, Pimley, \& Novacek, 1987) and psychological health (e.g. Görgen, Hiller, \& Witthöft, 2013). Coping and ER are also significant predictors of the quality of social relationships (Chang, 2009; Zambianchi \& Ricci Bitti, 2014), and connected also to well-being (Mayordomo-Rodrígues, Meléndez-Moral, Viguer-Segui, \& Sales-Galán, 2015). Therefore, it is important to understand the specificities of coping and ER processes. In the present study, we explored the possible age, gender and educational differences in specific periods of adulthood: emerging, young and middle adulthood. Over the past three decades, the delayed transition to adulthood observed in (post)industrial societies has been named emerging adulthood (e.g. Arnett, 2000), and is characterised by prolonged engagement in tertiary education, postponed marriage and parenthood, and a specific extended process of individualisation in relation to parents (e.g. Zupančič, Komidar, \& Puklek Levpušček, 2014). In young adulthood, individuals usually commit to a romantic partnership and have children; they finish their education, launch their career and establish independence (Kail \& Cavanaugh, 2013). In middle adulthood, individuals usually reorganise their family life due to their children's growing independence and their parents' increased need for help, while their primary developmental tasks are contributing to society and helping future generations (Kail \& Cavanaugh, 2013). The developmental specificities of each of these adult sub-groups may represent a different source of stress and consequently lead to differences between the groups regarding coping and ER. Both of these two processes will be presented, including their age, gender, and educational specificities.

Folkman, Lazarus, Gruen, and DeLongis (1986) defined coping as "constantly changing cognitive and behavioural efforts to manage specific external and/or internal demands that are appraised as taxing or exceeding the resources of the person" (p. 572). Coping strategies are usually divided into problem-focused and emotion-focused strategies. Problem-focused coping strategies (e.g. confrontive coping, planful problem-solving) involve attempts to reduce environment- 
DRUŠ. ISTRAŽ. ZAGREB GOD. 25 (2016), BR. 1 STR. 43-62

SMRTNIK VITULIĆ, H. \& PROSEN, S. COPING AND.. -related causes of stress, while emotion-focused coping strategies (e.g. distracting, positive reappraisal) include regulation of the negative emotional responses associated with stress (Folkman et al., 1986). Furthermore, coping strategies can be described as more active, dealing directly with the source of stress (e.g. confrontive coping, planful problem-solving, seeking social support) or more passive, meaning the absence of coping, avoiding or denying the problem (e.g. escape-avoidance) (e.g. Carver, Scheier, \& Weintraub, 1989). Using active coping strategies is generally thought to be more efficient in dealing with stressful events in comparison with the use of passive coping strategies (Glasscock, Andersen, Labriola, Rasmussen, \& Hansen, 2013). However, when evaluating strategies' efficiency, factors such as stress's nature, duration or controllability also have to be considered (Meléndez, Mayordomo, Sancho, \& Tomás, 2012).

Coping in adulthood was studied by Folkman and colleagues (1987), who found age-related differences between a group of younger/middle age adults (average age 41 years) and a group of older adults (average age 68 years). The younger group used problem-focused strategies of coping more frequently and emotion-focused forms of coping less frequently than the older group. Folkman and colleagues (1987) interpreted the differences between these groups with age-related differences in sources of stress (i.e. the younger group reported more difficulties related to work and child-rearing, whereas the older group had more health problems) and in an acquired style of dealing with unchangeable situations (greater use of positive reappraisal by the older group). Similarly, age differences in adulthood were confirmed in the study by Carver and Connor-Smith (2010, in Meléndez et al., 2012): with age people shift from more problem-focused coping to an emotion-focused one. Gender differences in coping were studied by Folkman and colleagues (1986, in Folkman et al., 1987), who found that women used more positive reappraisal than men, while men used more self-control than women. Meléndez and colleagues (2012) concluded that men more frequently than women use problem-focused coping strategies, while women use more emotion-focused ones. Folkman and colleagues (1987) found that older men used more passive coping strategies than younger men, while the opposite results were true for women. Meléndez and colleagues (2012) included three adult-age groups in their study (young, middle and elderly) and found some age-gender interaction effects: with age women's use of avoidance declines and negative self-focus and religion increase, while the trend is curvilinear in men. 
DRUŠ. ISTRAŽ. ZAGREB GOD. 25 (2016), BR. 1, STR. 43-62

SMRTNIK VITULIĆ, H. \& PROSEN, $S$ COPING AND...
In some contemporary studies, a link between coping and socioeconomic status (SES) has been found, with SES being indicated by the individual's level of education and income (e.g. Glasscock et al., 2013). Lower SES is associated with more intensive and longer exposure to stress, which may reduce the individual's ability to cope with it, is more likely to be connected with the use of less effective coping in response to stressful events and to perceiving fewer coping alternatives (Botchkovar, Tittle, \& Antonaccio, 2013; Glasscock et al., 2013). Studies on coping and SES interrelations in adulthood are scarce. In the study by Turner and Marino (1994, in Gayman, Cislo, Goidel, \& Ueno, 2014) adults with higher SES reported higher levels of coping resources like social support.

In addition to coping, ER is another regulatory process that has become an important topic across psychological research (Gross, 1998; Matsumoto, 2006). Gross (1998) defined ER as the process by which individuals influence which emotions they have, when they have them and how they experience and express them. In Gross and Thompson's (2009) process model, ER may be accomplished through: (1) Situation Selection - avoiding situations that may elicit emotions; (2) Situation Modification - changing a situation that may give rise to emotions; (3) Attentional Deployment - redirecting attention from an emotion-eliciting situation; (4) Cognitive Reappraisal changing the meaning or importance of a situation, (5) Response Modulation - changing experiential, physiological and behavioural response tendencies when emotions arise (e.g., suppression). The aforementioned ER strategies may be more or less efficient, as determined by various criteria such as functionality defined as goal accomplishment, adaptability representing alignment with the individual's specific contexts, and flexibility as the possibility to use different emotional responses (Thompson, 2011; Westphal, Seivert, \& Bonanno, 2010). Some ER strategies, such as suppression, are considered less efficient, and are significantly associated with more symptoms of psychopathology, whereas other ER strategies, such as reappraisal, are considered more efficient, and are associated with fewer symptoms of psychopathology (Aldao, Nolen-Hoeksema, \& Schweizer, 2010). The most evident developmental changes in ER occur from childhood to the end of adolescence. Following the occurrence of these changes, adult individuals are expected to become more responsible for managing their emotions, using more sophisticated and flexible ER strategies that take into account socio-cultural and personal goals (Thompson \& Meyer, 2009). However, ER in different adult sub-groups is not a well-studied field and some differences between these sub-groups may be speculated. 
DRUŠ. ISTRAŽ. ZAGREB GOD. 25 (2016), BR. 1 STR. 43-62

SMRTNIK VITULIĆ, H. \& PROSEN, S. COPING AND..
There are strong popular conceptions of gender differences in emotionality; for example, women are considered to be more emotional (McRae, Ochsner, Mauss, Gabrieli, \& Gross, 2008). The results of neurological measurements of ER sometimes show gender differences (McRae et al., 2008), which are explained as men using less effort for cognitive regulation because of their greater use of automatic ER and women using positive emotions to reappraise negative emotions more. To the best of our knowledge, there are no studies of differences in ER between adults with different levels of education. The present study can therefore supplement this research area.

Coping and ER are both conceptualised as processes of regulation (Compas at al., 2014) that are more or less conscious and controlled (Gross \& Thompson, 2009; Lazarus \& Folkman, 1987) and may change over time and in different situations (Compas at al., 2014). Although coping and ER may include similar strategies (e.g., reappraisal), coping can be considered a broader category than ER, as it includes both emotional and non-emotional responses to stress (Carver et al., 1989) and is limited to stress-eliciting situations (Lazarus \& Folkman, 1987), whereas ER only includes processes that elicit the individual's emotions (John \& Gross, 2009). However, a contrary perspective on the relationship between coping and ER also exists; namely, that ER is a broader category, as it includes the regulation of all emotions, whereas coping only includes the regulation of emotions in stressful circumstances (Compas et al., 2014). The aforementioned authors' discussion on the relation between coping and ER remains on a theoretical level and is - to our best knowledge - not supported by empirical data. It can be concluded that coping and ER are closely related but distinct processes, which is why it is interesting to study them together and understand their association further, as we have done in our study. As mentioned above, in our study, these two processes are compared in different periods of adulthood, also taking into account the participants' gender and educational specificities. The scientific contribution of the study lies in its simultaneous exploration of coping and ER processes in adulthood, including emerging adulthood, as a distinct sub-period of adulthood. Following hypotheses will be tested: the use of the majority of coping strategies will vary between adults in different age groups (H1), men and women $(\mathrm{H} 2)$ and different levels of education (H3). The use of the majority of ER strategies will also vary between adults in different age groups (H4), men and women (H5) and different levels of education (H6). Associations between coping and ER strategies will be mainly non-significant (H7). 
METHOD

\section{Participants}

(1) TABLE 1

Participants' age, gender and level of education
A convenience sample of a total of 194 adults aged between 20 and 65 years participated in our study (57.22\% men). The participants were divided into three groups according to age criteria defined by developmental psychology (Kail \& Cavanaugh, 2010; Zupančič et al., 2014): emerging adulthood from 20 to 29 years $(30.41 \%, M=24.59, S D=2.67)$, young adulthood from 30 to 45 years $(27.84 \%, M=38.43, S D=4.40)$, and middle adulthood from 46 to 65 years $(41.75 \%, M=50.44$, $S D=4.13)$. The participants were also divided into three groups according to their level of education: low with less than 12 years of education - primary and vocational school - $(21.13 \%)$, middle with 12 years of education - gymnasium, secondary school - $(23.20 \%)$, and high with more than 14 years of education - university and postgraduate education - $(55.67 \%)$.

\begin{tabular}{|c|c|c|c|c|c|c|}
\hline \multirow[b]{2}{*}{ Adults } & \multirow[b]{2}{*}{$\mathrm{N}$} & \multicolumn{2}{|r|}{ Gender } & \multicolumn{3}{|c|}{ Level of education } \\
\hline & & Men & Women & Low & Middle & High \\
\hline Emerging & 59 & 39 & 20 & 8 & 25 & 26 \\
\hline Young & 54 & 22 & 32 & 14 & 5 & 36 \\
\hline Middle & 81 & 50 & 31 & 19 & 15 & 46 \\
\hline Total & 194 & 111 & 83 & 41 & 45 & 108 \\
\hline
\end{tabular}

\section{Measures}

\section{Coping}

Coping was measured using the Slovene translation of a revised Ways of Coping Questionnaire (Folkman \& Lazarus, 1988, in Lamovec, 1994), which includes cognitive and behavioural strategies that people use in stressful situations. Participants were asked to self-assess their usual reaction in stressful situations, defined as difficult or taxing situation. There are 66 items that participants self-assess on a 4-point Likert scale $(0=$ not used, $1=$ used somewhat, $2=$ used quite a bit, $3=$ used $a$ great deal). Eight scales are derived from factor analysis (Folkman \& Lazarus, 1988, in Lamovec, 1994): (1) Confrontive Coping (six items, e.g., tried to get the person responsible to change his or her mind), (2) Distracting (six items, e.g., went on as if nothing had happened), (3) Self-Controlling (seven items, e.g., keep feelings to myself), (4) Seeking Social Support (six items, e.g., talked to someone who could do something concrete about the problem), (5) Accepting Responsibility (four items, e.g., criticised or lectured myself), (6) Escape-Avoidance (eight items, e.g., make myself feel better by eating, drinking, smoking, using drugs or medications, etc.), (7) Planful Problem-Solving (six items, e.g., made a plan of action 
DRUŠ. ISTRAŽ. ZAGREB GOD. 25 (2016), BR. 1 STR. 43-62

SMRTNIK VITULIĆ, H. \& PROSEN, S. COPING AND.. and followed it), and (8) Positive Reappraisal (seven items, e.g., found new faith). The Confrontive Coping and Planful Problem-Solving scales primarily describe problem-focused coping strategies, while the Distracting, Self-Controlling, Accepting Responsibility, Escape-Avoidance, and Positive Reappraisal scales primarily describe emotion-focused coping strategies. The Seeking Social Support scale describes both types of coping strategies (Folkman et al., 1987). Folkman, Lazarus, Dunkel-Schetter, DeLongis, and Gruen (1986) reported internal reliabilities (Cronbach $\alpha$ s) for Confrontive Coping, Distracting, Self-Controlling, Seeking Social Support, Accepting Responsibility, Escape-Avoidance, Planful Problem-Solving and Positive Reappraisal of $0.70,0.61,0.70,0.76,0.66,0.72,0.68$, and 0.79 , respectively. In our study, internal reliabilities (Cronbach $\alpha$ s) for six scales are above 0.60 (from 0.63 to 0.72 ), confirming that these reliabilities are acceptable as recommended by Ferligoj, Leskošek and Kogovšek (1995). However, internal reliabilities of the Self-Controlling and Accepting Responsibility scales are below 0.60 , with $\alpha_{s} 0.47$ and 0.51 , respectively. Therefore, the results of these two scales should be interpreted with caution.

\section{Emotion regulation}

The Emotion Regulation Strategies Questionnaire (ERSQ), based on Gross and Thompson's (2009) model of ER, was used. The questionnaire was designed by the authors of the article and includes the following ER strategies, each represented by one item: (1) Situation Selection (i.e. avoid the unpleasant situation), (2) Situation Modification (i.e. change the unpleasant situation), (3) Attentional Deployment (i.e. think of something pleasant), (4) Cognitive Reappraisal of a situation's meaning (i.e. look at the situation from another perspective) and importance (i.e. lessen the situation's importance), and (5) Response Modulation: experiential (i.e. switch off my emotions), physiological (i.e. relax my body) and behavioural. All of these ER strategies are defined in the introduction of this article. Within the behavioural response modulation strategy, a distinction was made between (a) physical activation (i.e. go for a walk), (b) suppression defined as the reduced expression or non-expression of emotions (i.e. hide emotions in front of the others), (c) seeking social support (i.e. find someone to help me), (d) comfort eating (i.e. eat something good when feeling unpleasant emotions), and (e) psycho-active substance use (i.e. take a pill or drink alcohol when feeling unpleasant emotions). For each ER strategy, the participants of the study were asked to assess how often - on average - they use it on a five-point Likert-type scale $(1=$ never use, $2=$ rarely use, $3=$ sometimes use, $4=$ frequently use, $5=$ almost always use). 


\section{Procedure and statistical analysis}

Students of the Faculty of Education, University of Ljubljana, attending a developmental psychology course were asked to invite their relatives, friends and/or acquaintances aged between 20 and 65 years to participate in our study on coping and ER strategies in adulthood. Those willing to participate then received written information about the study and questionnaires. The students brought the completed questionnaires in the sealed envelopes.

Non-parametric statistical procedures were used in data analysis, as the normality of distribution for the average score of each coping and ER strategy was not confirmed (ShapiroWilk tests and Kolmogorov-Smirnov tests, all $p_{\mathrm{s}}<0.00$ ). The median was calculated for each coping and ER strategy, and Kruskal-Wallis tests were used to compare the results of coping and ER strategies between the three sub-groups of adults and between the three sub-groups based on different educational levels. If the differences between the groups were significant, Mann-Whitney tests were applied to determine the differences between each pair of groups. Mann-Whitney tests were also used to define gender differences, while Spearman's rhos were used to identify the correlations between coping and ER strategies.

RESULTS

In the results section, the analysis of coping strategies will be followed by the analysis of ER strategies. In both cases, the strategies are compared regarding the age, gender and education level of the participants.

\section{Coping strategies}

There are no significant differences in coping strategies between the age groups of emerging, young and middle adults (Kruskal-Wallis test; $p>0.05$ ). All of the groups use coping strategies similarly, and the average scores (Mes) (Table 1) for each coping strategy can therefore be analysed for all three groups together. The medians range between 0.88 (EscapeAvoidance) and 1.75 (Accepting Responsibility). When analysing the more and less frequent use of coping strategies in adults, the criteria of $M e<0.5$ and $M e>1.5$ were applied for their rare and frequent use, respectively. If $0.5 \leq M e \leq 1.5$, it is referred to as a sometimes used strategy.

Among coping strategies, their frequency of use is presented in Table 2. When comparing adults regarding their gender, no significant differences between men and women are confirmed in their use of coping strategies (Kruskal-Wallis 
DRUŠ. ISTRAŽ. ZAGREB GOD. 25 (2016), BR. 1 STR. 43-62

SMRTNIK VITULIĆ, H. \& PROSEN, S.

COPING AND..

TABLE 2

Medians and frequency of use of coping strategies in adulthood
(1) TABLE 3

Significant differences in mean ranks of use of coping strategies between adults with different levels of education test; $p>0.05)$. However, significant differences in three coping strategies are identified between adults with a different educational level (Table 2): Confrontive Coping, Distracting and Escape-Avoidance.

\begin{tabular}{lcr}
\hline Coping Strategy & Me & Frequency of Use \\
\hline Confrontive Coping & 1.24 & sometimes \\
Distracting & 1.17 & sometimes \\
Self-Controlling & 1.43 & sometimes \\
Seeking Social Support & 1.33 & sometimes \\
Accepting Responsibility & 1.75 & frequently \\
Escape-Avoidance & 0.88 & sometimes \\
Planful Problem-Solving & 1.83 & frequently \\
Positive Reappraisal & 1.57 & frequently \\
\end{tabular}

Note: $M e=$ median of frequency of use of coping strategy.

Adults with a low level of education use Confrontive Coping, Distracting and Escape-Avoiding strategies significantly more frequently than adults with a high level of education. The Escape-Avoiding strategy is also used significantly more frequently by adults with a middle level of education in comparison to those with a high level of education.

\begin{tabular}{lrrrrr}
\hline Coping Strategy & $\begin{array}{r}\text { Low (I) R } \\
(n=41)\end{array}$ & $\begin{array}{r}\text { Middle (II) R } \\
(n=45)\end{array}$ & $\begin{array}{r}\text { High (III) R } \\
(n=107)\end{array}$ & $\begin{array}{r}\text { Kruskal-Wallis } \\
\text { test } \chi^{2}(d f) p\end{array}$ & $\begin{array}{r}\text { Mann-Whitney } \\
\text { test differences }\end{array}$ \\
\hline Confrontive Coping & 112.96 & 101.70 & 85.19 & $8.42(2) 0.015$ & I $>$ III \\
Distracting & 121.64 & 101.70 & 85.63 & $12.60(2) 0.002$ & I $>$ III \\
Escape-Avoidance & 116.68 & 108.83 & 83.77 & $13.19(2) 0.001$ & I $>$ III $/$ II $>$ III
\end{tabular}

Note: $\mathrm{R}=$ mean rank; $>$ the first group perceived the coping strategies as more frequently used than the second; Low (I) = finished primary and vocational school ( $<12$ years of education); Middle (II) = finished secondary school or gymnasium (12 years of education); High (III) = finished university and postgraduate education (> 14 years of education).

\section{ER strategies}

The comparison of different age sub-groups in adulthood regarding their use of selected ER strategies shows only one significant difference in mean ranks: Cognitive Reappraisal of the situation's importance (Kruskall-Wallis test: $\chi^{2}(2)=8.59$; $p=0.014 ;$ Remerging adult $=79.29 ;$ Ryoung adult $=104.19$; Rmiddle adult $=102.99)$. Mann-Whitney tests confirmed that young adults use this strategy significantly more than emerging adults. As this is the only difference between the groups, further analysis of average scores of ER strategies is performed for all of the adults together. 
DRUŠ. ISTRAŽ. ZAGREB GOD. 25 (2016), BR. 1, STR. 43-62

SMRTNIK VITULIĆ, H. \& PROSEN, S. COPING AND...

? TABLE 4 Medians of use of ER strategies for all adults
(1) TABLE 5

Significant differences in mean ranks of use of ER strategies between women and men
The average scores of the ER strategies are presented following Gross and Thompson's (2009) process model of ER (Table 3). Each strategy is also commented upon regarding its frequency of use, applying the criteria of $M e>3.5$ as frequently, $2.5 \leq M e \leq 3.5$ as sometimes, and $M e<2.5$ as rarely used ER strategy. Average scores $(\mathrm{Mes})$ for all ER strategies range between 1.00 and 4.00 .

\begin{tabular}{llcr}
\hline ER Strategy & & Me & $\begin{array}{r}\text { Frequency } \\
\text { of Use }\end{array}$ \\
\hline $\begin{array}{l}\text { Situation Selection } \\
\text { Situation Modification }\end{array}$ & & 4.00 & $\begin{array}{r}\text { frequently } \\
\text { frequently }\end{array}$ \\
Attentional Deployment & & 4.00 & frequetimes \\
Cognitive Reappraisal & Meaning & 3.00 & sometion \\
& Importance & 3.00 & sometimes \\
Response Modulation & Experiential & 2.00 & sometimes \\
& Physiological & 3.00 & sometimes \\
Behavioural & Physical Activation & 3.00 & sometimes \\
& Suppression & 4.00 & frequently \\
& Social Support & 3.00 & sometimes \\
& Comfort Eating & 2.00 & rarely \\
& Substance Use & 1.00 & rarely \\
\hline
\end{tabular}

Note: $M e=$ median of frequency of use of ER strategy.

Among ER strategies, their frequency of use is presented in Table 4. Gender differences in the use of ER strategies (Table 4) are confirmed for: Attentional Deployment, Cognitive Reappraisal of Importance and Physiological Response Modulation, as well as Physical Activation, Social Support and Comfort Eating among behavioural response modulation strategies.

\begin{tabular}{lrrrr}
\hline ER Strategy & $\begin{array}{r}\text { Female R } \\
(n=111)\end{array}$ & $\begin{array}{r}\text { Male R } \\
(n=83)\end{array}$ & $\begin{array}{r}\text { Mann-Whitney test } \\
\chi^{2}(d f) p\end{array}$ & $\begin{array}{r}\text { Mann-Whitney } \\
\text { test differences }\end{array}$ \\
\hline $\begin{array}{l}\text { Attentional Deployment } \\
\text { Cognitive Reappraisal }\end{array}$ & 202.81 & 89.14 & $4.29(1) 0.038$ & $\mathrm{~F}>\mathrm{M}$ \\
$\begin{array}{l}\text { Importance } \\
\text { Response Modulation }\end{array}$ & 187.49 & 86.48 & $8.28(1) 0.004$ & $\mathrm{~F}>\mathrm{M}$ \\
$\quad \begin{array}{l}\text { Physiological } \\
\text { Behavioural }\end{array}$ & 165.35 & 89.01 & $4.31(1) 0.038$ & $\mathrm{~F}>\mathrm{M}$ \\
$\quad \begin{array}{l}\text { Physical Activation } \\
\text { Social Support }\end{array}$ & 103.22 & 86.17 & $8.72(1) 0.003$ & $\mathrm{~F}>\mathrm{M}$ \\
Comfort Eating & 110.08 & 87.03 & $7.20(1) 0.007$ & $\mathrm{~F}>\mathrm{M}$ \\
& 110.08 & 89.39 & $3.91(1) 0.048$ & $\mathrm{~F}>\mathrm{M}$ \\
\hline
\end{tabular}

Note: $\mathrm{R}=$ mean rank; $>$ the first group perceived ER as more frequently used than the second; $\mathrm{F}=$ female, $\mathrm{M}=$ male. 
(1) TABLE 6

Significant differences in mean ranks of use of ER strategies between adults with different levels of education
It can be observed from the Mann-Whitney tests and mean ranks that women use the ER strategies listed in Table 4 significantly more than men. The results also show significant differences in three ER strategies of adults regarding their level of education (Table 5): Cognitive Reappraisal of the importance of the situation, Suppression, and Substance Use.

\begin{tabular}{lcrrrr}
\hline ER Strategy & $\begin{array}{r}\text { Low (I) R } \\
(n=41)\end{array}$ & $\begin{array}{r}\text { Middle (II) R } \\
(n=45)\end{array}$ & $\begin{array}{r}\text { High (III) R } \\
(n=107)\end{array}$ & $\begin{array}{r}\text { Kruskal-Wallis } \\
\text { test } \chi^{2}(d f) p\end{array}$ & $\begin{array}{r}\text { Mann-Whitney } \\
\text { test differences }\end{array}$ \\
\hline $\begin{array}{l}\text { Cognitive Reappraisal } \\
\text { Importance }\end{array}$ & 111.48 & 81.88 & 95.25 & $6.74(2) 0.034$ & I > II / I > III \\
$\begin{array}{l}\text { Behavioural Res- } \\
\text { ponse Modulation }\end{array}$ & & & & & \\
$\quad \begin{array}{l}\text { Suppression } \\
\quad \text { Substance Use }\end{array}$ & 115.95 & 97.34 & 86.92 & $9.22(2) 0.010$ & I > III \\
\hline
\end{tabular}

Note: $\mathrm{R}=$ mean rank; $>$ the first group perceived coping strategies as more frequently used than the second; Low $(\mathrm{I})=$ finished primary and vocational school ( $<12$ years of education); Middle (II) = finished secondary school or gymnasium (12 years of education); High (III) = finished university and postgraduate education ( $>14$ years of education).

Adults with a low level of education more frequently use Cognitive Reappraisal of Importance, Suppression and Substance Use in comparison to adults with a high level of education. Cognitive Reappraisal of Importance is also more frequently used by adults with a low level of education in comparison to adults with a middle level of education.

\section{Associations between coping and ER strategies}

The correlations between coping and ER strategies included in our study are mainly non-significant. The majority of the significant correlations are small, ${ }^{1}$ while the others are moderately high (Table 6), which suggests a relatively low association of these two categories of regulatory strategies. Important and moderately high positive correlations are only found between seven pairs of coping and ER strategies: between Seeking Social Support and Social Support, between Escape-Avoidance and Comfort Eating, between Escape-Avoidance and Substance Use, between Planful Problem-Solving and Cognitive Reappraisal of Meaning, between Positive Reappraisal and Attentional Deployment, between Positive Reappraisal and Physiological Response Modulation, and between Positive Reappraisal and Physical Activation.

${ }^{1}$ Cohen (1988) suggested that values of correlations $\geq 0.10$ and $<0.30$ indicate relationships of a small magnitude, and values between $0.30-0.49$ and $>0.50$ indicate moderate and high magnitudes, respectively. 


\begin{tabular}{|c|c|c|c|c|c|c|c|c|}
\hline \multirow{3}{*}{$\begin{array}{l}\text { (1) TABLE } 7 \\
\text { Spearman rho } \\
\text { correlations between } \\
\text { coping and ER } \\
\text { strategies in adults } \\
\text { ER Strategy }\end{array}$} & \\
\hline & \multicolumn{8}{|c|}{ Coping Strategy } \\
\hline & $\begin{array}{l}\text { Con- } \\
\text { frontive } \\
\text { Coping }\end{array}$ & Distracting & $\begin{array}{l}\text { Self- } \\
\text {-Con- } \\
\text { trolling }\end{array}$ & $\begin{array}{l}\text { Seeking } \\
\text { Social } \\
\text { Support }\end{array}$ & $\begin{array}{l}\text { Accepting } \\
\text { Respon- } \\
\text { sibility }\end{array}$ & $\begin{array}{l}\text { Escape- } \\
\text {-Avoidance }\end{array}$ & $\begin{array}{l}\text { Planful } \\
\text { Problem- } \\
\text {-Solving }\end{array}$ & $\begin{array}{l}\text { Positive } \\
\text { Reap- } \\
\text { praisal }\end{array}$ \\
\hline Situation Selection & $0.26^{* *}$ & $0.20^{* *}$ & $0.17^{*}$ & 0.12 & $0.15^{*}$ & 0.07 & $0.17^{*}$ & $0.15^{*}$ \\
\hline Situation Modification & 0.10 & $0.17^{*}$ & $0.16^{*}$ & -0.04 & $0.16^{*}$ & $0.25^{* *}$ & -0.03 & 0.03 \\
\hline Attentional Deployment & 0.13 & $0.14^{*}$ & $0.17^{*}$ & 0.14 & $0.21^{* *}$ & 0.12 & $0.18^{*}$ & $0.30^{* *}$ \\
\hline \multicolumn{9}{|l|}{ Cognitive Reappraisal } \\
\hline Meaning & -0.04 & 0.03 & 0.14 & 0.08 & $0.14^{*}$ & $-0.16^{*}$ & $0.31^{* *}$ & $0.28^{* *}$ \\
\hline Importance & 0.14 & $0.25^{* *}$ & 0.09 & 0.11 & $0.20^{*}$ & $0.20^{*}$ & 0.12 & $0.16^{*}$ \\
\hline \multicolumn{9}{|l|}{ Response Modulation } \\
\hline Experiential & 0.19 & $0.25^{* *}$ & -0.03 & -0.11 & -0.09 & 0.10 & 0.11 & -0.04 \\
\hline Physiological & 0.10 & 0.08 & 0.05 & $0.29 * *$ & 0.11 & 0.06 & $0.26^{* *}$ & $0.33^{* *}$ \\
\hline \multicolumn{9}{|l|}{ Behavioural } \\
\hline Physical Activation & 0.08 & 0.13 & $0.15^{*}$ & $0.16^{*}$ & $0.25^{* *}$ & 0.00 & $0.15^{*}$ & $0.32^{* *}$ \\
\hline Suppression & 0.09 & $0.24^{* *}$ & $0.21^{* *}$ & -0.04 & $0.15^{*}$ & 0.12 & 0.01 & 0.13 \\
\hline Social Support & $0.25^{* *}$ & 0.05 & $0.22 *$ & $0.36^{* *}$ & 0.13 & $0.17^{*}$ & -0.01 & $0.21^{* *}$ \\
\hline Comfort Eating & $0.26^{* *}$ & $0.23^{* *}$ & 0.14 & 0.06 & 0.11 & $0.32^{* *}$ & -0.08 & 0.05 \\
\hline Substance Use & $0.16^{*}$ & $0.15^{*}$ & 0.04 & 0.03 & 0.05 & $0.45^{* *}$ & -0.04 & 0.00 \\
\hline
\end{tabular}

Note: ${ }^{*} p<0.05 ;{ }^{* *} p<0.01$

\section{DISCUSSION}

Emerging, young and middle adulthood offer somewhat different developmental tasks to be mastered by representatives of these age periods: emerging adults deal with prolonged education and an extended process of individualisation (e.g. Arnett, 2000; Zupančič et al., 2014), young adults usually create their own families, commence their career and establish independence, while middle adults' primary developmental task is helping future generations (Kail \& Cavanaugh, 2010). Differences in the sources of stress between individuals in these age periods are therefore to be expected, as is their different use of strategies to cope with these situations (e.g. Folkman et al., 1987). Despite this, the results of our study show no age differences in the use of coping strategies between the groups of adults included (thus declining the first hypothesis), suggesting that adults use coping strategies in a similar way, even though they may face different sources of stress. In contrast to our results, Folkman and colleagues (1987) and Carver and Connor-Smith (2010, in Meléndez et al., 2012) found that an older group of adults used more emotion-focused strategies of coping in comparison to a younger group of adults. The differences between the results of this study and these two studies could be attributed to possible cultural differences, as well as to the different age groups of the participants included in the studies.

Since the results of our study show similar use of coping strategies in emerging, young and middle adults, we present 
DRUŠ. ISTRAŽ. ZAGREB GOD. 25 (2016), BR. 1 STR. 43-62

SMRTNIK VITULIĆ, H. \& PROSEN, $S$. COPING AND.. these results together. Adults use different coping strategies, but more or less frequently. They sometimes escape from or avoid stress situations (Escape-Avoiding), confront the situation (Confrontive Coping), distract themselves (Distracting), exercise self-control (Self-Controlling) or seek social support (Seeking Social Support), while they frequently accept responsibility for the situation (Accepting Responsibility), clearly plan its solution (Planful Problem-Solving) or reappraise the situation in a more positive way (Positive Reappraisal). Adults seem to sometimes or frequently use both problem-focused strategies (attempts to reduce environment-related causes of stress) and emotion-focused coping strategies (regulation of the negative emotional responses associated with stress) (Folkman et al., 1986). Furthermore, the more used coping strategies in our study can be described as more active, and hence can be also regarded as more efficient (Glasscock et al., 2013). Our results are therefore encouraging.

As there are no significant differences between the age groups of adults in their use of coping strategies, differences in coping regarding gender and level of education are therefore analysed for all participants together. Folkman and colleagues (1986, in Folkman et al., 1987) concluded that women reframe the situation's meaning in a positive way (Positive Reappraisal) more frequently than men, while men keep their emotions to themselves (Self-Controlling) more frequently than women. Also, Meléndez and colleagues (2012) found that men more frequently than women use problem-focused coping strategies, while women use more emotion-focused ones. These gender differences in coping strategies were expected due to Western societal values that encourage men not to express their emotions (Folkman et al., 1987). However, our results are not in line with these expectations, as we found no gender differences in the adults participating in our study (thus declining the second hypothesis). The reasons for non-occurrence of gender differences remains open for further research.

The third hypothesis suggesting the existence of differences in coping strategies used between adults with different levels of education has been declined, although some differences between these groups do exist. Adults with a low level of education (primary or vocational school) use direct confrontation with others (Confrontive Coping), distance themselves from or deny the situation (Distracting) and escape from or avoid the situation (Escape-Avoidance) more frequently than adults with a high educational level (university or postgraduate studies). Adults with a middle level of education (secondary school or gymnasium) also use the Escape-Avoidance strategy more than adults with a high educational level. The more frequent use of these somewhat less efficient coping 
DRUŠ. ISTRAŽ. ZAGREB GOD. 25 (2016), BR. 1, STR. 43-62

SMRTNIK VITULIĆ, H. \& PROSEN, $S$ COPING AND. strategies in adults with a low educational level could perhaps be a consequence of their worse employment possibilities and lower income, which may lead to longer and more intense exposure to stress, consequently reducing their ability to cope (e.g. Botchkovar et al., 2013; Glasscock et al., 2013). Concurring with their interpretation, we can conclude that, due to a lower level of coping resources, a lower educational level may contribute to the individual's more intensive feeling of helplessness in stress situations, and to the more frequent use of passive coping strategies such as Distracting and Escape-Avoidance. However, the more frequent use of Confrontive Coping in adults with a low level of education needs further exploration since the described differences may be partly due to the unequal number of representatives of each level of education in our study.

Another regulatory process examined in our study is ER: strategies that adults use to regulate their emotions. Just as for coping, ER strategies are compared in different age groups of adults and regarding the adults' gender and level of education. With one exception - young adults use cognitive reappraisal of the situation's importance more than emerging adults - age groups use the selected ER strategies similarly (thus declining the fourth hypothesis), and the results are therefore discussed for all age groups together. Among ER strategies that follow Gross and Thompson's (2009) model, adults frequently select or modify situations that may elicit their emotions (Situation Selection and Situation Modification), and when emotions arise they try to suppress them (Suppression). Suppression is considered less efficient as it creates a discrepancy between inner experience and outer expression, and its frequent use may be negatively linked to well-being and social functioning (Gross \& John, 2003). Adults should therefore be given information regarding the consequences of the frequent use of this strategy.

Adults sometimes redirect attention from the emotional situation to something else (Attentional Deployment), use a cognitive reappraisal of the situation's meaning and importance, influence the physiological processes accompanying the emotions, change emotions via physical activation, and seek social support. As attentional deployment is more common in children, its rather frequent use by adults is interesting. The only moderate use of reappraisal is also surprising, as it is usually listed among effective ER strategies connected to well-being, self-esteem and having social support (Gross \& John, 2003). Adults also try to influence their emotions through physiological processes (i.e. breathing evenly), physical activation and social support seeking, which may be efficient strategies according to some authors (e.g. Milivojević, 2008), 
DRUŠ. ISTRAŽ. ZAGREB GOD. 25 (2016), BR. 1 STR. 43-62

SMRTNIK VITULIĆ, H. \& PROSEN, $S$. COPING AND.. and their moderate use should therefore be encouraged. Adults rarely use experiential response modulation, meaning they rarely "switch off" their emotional experience. They also rarely use food or psychoactive substances to comfort their emotions, probably as they are well aware of the possible negative consequences.

Adult women in our study use attentional deployment and cognitive reappraisal of the situation's importance more than men. They also try to influence their physiological processes, use more physical activation, seek social support, and eat in order to regulate emotions more frequently than men. It can therefore be concluded that there are certain differences between men and women regarding their ER (but not enough to confirm the fifth hypothesis), which concurs with the conclusions of some other authors (e.g. Flynn, Hollenstein, \& Mackey, 2010), who report certain gender differences. Our results are also in line with data gathered in neurological research by McRae and colleagues (2008), indicating that women try harder when dealing with emotions than men.

Adults with low and middle levels of education report the more frequent use of cognitive reappraisal of the situation's importance in comparison with adults whose level of education is high. Furthermore, adults with a low level of education use suppression and substances when dealing with emotions more than adults with a high educational level. Considering these differences (that are not enough to confirm the sixth hypothesis), adults with a lower educational level in particular could benefit from information about the possible negative consequences of very frequent suppression and substance use when regulating emotions.

Various authors (e.g. Compas et al., 2014) are still seeking consensus regarding coping and ER, attempting to determine whether these two processes are the same or which of them includes the other. The correlation analysis provided by our study contributes further information to this discussion. In our study, coping and ER strategies are mostly non-associated (confirming the seventh hypothesis), which may lead to the conclusion that coping and ER are two mainly distinct processes. The distinction between these two processes may be explained by the fact that coping represents - and is measured as - a reaction to stress situations, while ER describes and is measured as - dealing with emotions. That means that the use of coping strategies is always connected to a stressful situation while the use of ER strategies is always connected to emotional experience. Therefore, the apparently similar strategies included in the questionnaires (e.g. Positive Reappraisal as a coping strategy and Cognitive Reappraisal as an ER strategy) describe different strategies, and they are not used 
DRUŠ. ISTRAŽ. ZAGREB STR. 43-62

SMRTNIK VITULIĆ, H. \& PROSEN, S COPING AND... GOD. 25 (2016), BR. 1,

with a similar level of frequency by the adults included in our study. On the other hand, there are some significant correlations between coping and ER strategies in our study. The majority of these correlations are small, but some of them are moderately high, suggesting a link between coping and ER processes. Adults can react similarly in stressful and emotional situations; for example, adults who tend to seek social support do so regardless of whether they are dealing with stress or "just" emotion.

\section{CONCLUSION}

In the present study, gender and educational specificities of coping and ER strategies in emerging, young and middle adulthood are analysed. Adults in all three age sub-groups are similar in their frequency of use of coping and ER strategies, with the exception of young adults, who reappraise the situation's importance more than emerging adults. Gender differences do not appear regarding the use of coping strategies, although women do apply certain ER strategies more than men. The educational level of adults plays an important role regarding their use of some coping and ER strategies. Specifically, adults with a low level of education use somewhat less efficient strategies in comparison with adults with a high level of education. Given the mostly non-significant associations between coping and ER strategies in our study, coping and ER may be understood as distinct processes in adulthood.

The novelty of our research lies in its simultaneous exploration of coping and ER processes, with special attention being focused on their use with regard to age, gender and educational specificities in adulthood. Furthermore, emerging adulthood, as a distinct sub-period of adulthood, is analysed regarding coping and ER for the first time. On the other hand, the specific characteristics of the sample (relatively small number, more participants with a high level of education) should be considered as a shortcoming of our study. Furthermore, participants assessed the use of regulation strategies in general, across situations. The assessment of strategies used in a specific context could provide a more detailed picture of the regulation specificities. Also, the internal reliabilities of two of the coping strategies' scales are lower. For these reasons, the results should be generalised with caution. Since adults self-assessed their coping and ER strategies, their subjectivity should also be considered. The practical implications of the study may include courses designed to teach effective coping and ER strategies tailored to specific groups of adults, considering their age, gender or educational specificities. In the future, research designs aimed at coping and ER processes 
within specific contexts, addressing specific sources of stress and combining different methodological approaches could be applied.

\section{REFERENCES}

Aldao, A., Nolen-Hoeksema, S., \& Schweizer, S. (2010). Emotion-regulation strategies across psychopathology: A meta-analytic review. Clinical Psychology Review, 30(2), 217-237. doi:10.1016/j.cpr.2009.11.004

Arnett, J. J. (2000). Emerging adulthood: A theory of development from the late teens through the twenties. American Psychologist, 55(5), 469-480. doi:10.1037//0003-066X.55.5.469

Bonanno, G. A., \& Burton, C. L. (2013). Regulatory flexibility. An individual differences perspective on coping and emotion regulation. Perspectives on Psychological Science, 8(6), 591-612. doi:10.1177/ 1745691613504116

Botchkovar, E. V., Tittle, C. R., \& Antonaccio, O. (2013). Strain, coping, and socioeconomic status: Coping histories and present choices. Journal of Quantitative Criminology, 29(2), 217-250. doi:10.1007/s10940012-9177-7

Carver, C. S., Scheier, M. F., \& Weintraub, J. K. (1989). Assessing coping strategies: A theoretically based approach. Journal of Personality and Social Psychology, 56(2), 267-283. doi:10.1037/0022-3514.56.2.267

Chang, M. L. (2009). Teacher emotional management in the classroom: Appraisals, regulation, and coping with emotions. Paper presented at the 2009 annual meeting of the American Educational Research Association, San Diego, CA.

Cohen, J. (1988). Statistical power analysis for the behavioural sciences. Hillsdale, NJ: Erlbaum.

Compas, B. E., Jaser, S. S., Dunbar, J. P., Watson, K. H., Bettis, A. H., Gruhn, M. A., \& Williams, E. K. (2014). Coping and emotion regulation from childhood to early adulthood: Points of convergence and divergence. Australian Journal of Psychology, 66(2), 71-81. doi:10.1111/ ajpy.12043

Ferligoj, A., Leskošek, K., \& Kogovšek, T. (1995). Zanesljivost in veljavnost merjenja [Reliability and validity of measurement]. Ljubljana: FDV.

Flynn, J. J., Hollenstein, T., \& Mackey, A. (2010). The effect of suppressing and not accepting emotions on depressive symptoms: Is suppression different for men and women? Personality and Individual Differences, 49(6), 582-586. doi:10.1016/j.paid.2010.05.022

Folkman, S., Lazarus, R. S., Dunkel-Schetter, C., DeLongis, A., \& Gruen, R. J. (1986). Dynamics of a stressful encounter: Cognitive appraisal, coping and encounter outcomes. Journal of Personality and Social Psychology, 50(5), 992-1003. doi:10.1037/0022-3514.50.5.992

Folkman, S., Lazarus, R. S., Gruen, R. J., \& DeLongis, A. (1986). Appraisal, coping, health status, and psychological symptoms. Journal of Personality and Social Psychology, 50(3), 571-579. doi:10.1037/00223514.50.3.571

Folkman, S., Lazarus, R. S., Pimley, S., \& Novacek, J. (1987). Age differences in stress and coping processes. Psychology and Aging, 2(2), 171-184. doi:10.1037/0882-7974.2.2.171 
DRUŠ. ISTRAŽ. ZAGREB GOD. 25 (2016), BR. 1, STR. 43-62

SMRTNIK VITULIĆ, H. \& PROSEN, S COPING AND...
Gayman, M. D., Cislo, A. M., Goidel, A. R., \& Ueno, K. (2014). SES and race-ethnic differences in the stress-buffering effects of coping resources among young adults. Ethnicity \& Health, 19(2), 198-216. doi:10.1080/13557858.2013.828827

Glasscock, D. J., Andersen, J. H., Labriola, M., Rasmussen, K. \& Hansen, C. D. (2013). Can negative life events and coping style help explain socioeconomic differences in perceived stress among adolescents? A cross-sectional study based on the West Jutland cohort study. BMC Public Health, 13, 532. doi:10.1186/1471-2458-13-532

Görgen, S. M., Hiller, W. H., \& Witthöft, M. (2013). Health anxiety, cognitive coping, and emotional regulation: A latent variable approach International Society of Behavioral Medicine, 21(2), 364-374. doi:10.1007/ s12529-013-9297-y

Gross, J. J. (1998). The emerging field of emotion regulation: An integrative review. Review of General Psychology, 2(3), 271-299. doi:10.1037/ 1089-2680.2.3.271

Gross, J. J., \& John, O. P. (2003). Individual differences in two emotion regulation processes: Implications for affect, relationships, and well-being. Journal of Personality and Social Psychology, 85(2), 348-362. doi:10.1037/0022-3514.85.2.348

Gross, J. J., \& Thompson, R. A. (2009). Emotion regulation: Conceptual foundations. In J. J. Gross, \& R. A. Thompson (Eds.), Handbook of emotion regulation (pp. 3-24). New York, London: The Guilford Press. John, O. P., \& Gross, J. J. (2009). Individual differences in emotion regulation. In J. J. Gross, \& R. A. Thompson (Eds.), Handbook of emotion regulation (pp. 351-372). New York, London: The Guilford Press.

Kail, R. V., \& Cavanaugh, J. C. (2013). Human development - a life-span view. Belmont: Wadsworth.

Lamovec, T. (Ed.) (1994). Psihodiagnostika osebnosti 1 [Psychodiagnostics of personality 1]. Ljubljana: Oddelek za psihologijo, Filozofska fakulteta.

Lazarus, R. S., \& Folkman, S. (1987). Transactional theory and research on emotions and coping. European Journal of Personality, 1(3), 141-169. doi:10.1002/per.2410010304

Matsumoto, D. (2006). Are cultural differences in emotion regulation mediated by personality traits? Journal of Cross-Cultural Psychology, 37(4), 421-437. doi:10.1177/0022022106288478

Mayordomo-Rodrígues, T., Meléndez-Moral, J. C., Viguer-Segui, P., \& Sales-Galán, A. (2015). Coping strategies as predictors of well-being in youth adult. Social Indicators Research, 122(2), 479-489. doi:10.1007/ s11205-014-0689-4

McRae, K., Ochsner, K. N., Mauss, I. B., Gabrieli, J. J. D., \& Gross, J. J. (2008). Gender differences in emotion regulation: An fMRI study of cognitive reappraisal. Group Processes E Intergroup Relations, 11(2), 145-162. doi:10.1177/1368430207088035

Meléndez, J. C., Mayordomo, T., Sancho, P., \& Tomás, J. M. (2012). Coping strategies: Gender differences and development throughout life span. The Spanish Journal of Psychology, 15(3), 1089-1098. doi:10. 5209/rev_SJOP.2012.v15.n3.39399 
DRUŠ. ISTRAŽ. ZAGREB GOD. 25 (2016), BR. 1 STR. $43-62$

SMRTNIK VITULIĆ, H. \& PROSEN, $S$ COPING AND..
Milivojević, Z. (2008). Emocije: Razumevanje čustev v psihoterapiji [Emotions: Understanding emotions in psychotherapy]. Novi Sad: Psihopolis institut.

Thompson, R. A. (2011). Emotion and emotion regulation: Two sides of the developing coin. Emotion Review, 3(1), 53-61. doi:10.1177/175 4073910380969

Thompson, R. A., \& Meyer, S. (2009). Socialization of emotion regulation in the family. In J. J. Gross, \& R. A. Thompson (Eds.), Handbook of emotion regulation (pp. 249-268). New York, London: The Guilford Press.

Westphal, M., Seivert, N. H., \& Bonanno, G. A. (2010). Expressive flexibility. Emotion, 10(1), 92-100. doi:10.1037/a0018420

Zambianchi, M., \& Ricci Bitti, P. E. (2014). The role of proactive coping strategies, time perspective, perceived efficacy on affect regulation, divergent thinking and family communication in promoting social well-being in emerging adulthood. Social Indicators Research, 116(2), 493-507. doi:10.1007/s11205-013-0307-x

Zupančič, M., Komidar, L., \& Puklek Levpušček, M. (2014). Individuation in Slovene emerging adults: Its associations with demographics, transitional markers, achieved criteria for adulthood, and life satisfaction. Journal of Adolescence, 37(8), 1421-1433. doi:10.1016/ j.adolescence.2014.03.014

\section{Strategije suočavanja i \\ emocionalne regulacije $u$ odrasloj dobi: specifičnosti s obzirom na dob, spol i razinu obrazovanja}

Helena SMRTNIK VITULIĆ i Simona PROSEN

Pedagoški fakultet, Ljubljana

U radu se uspoređuje primjena strategija suočavanja i emocionalne regulaciije (ER) kod 194 odrasle osobe između 20 i 65 godina, s obzirom na dob (odrasli u nastajanju, odrasli mlade dobi i odrasli srednje dobi), spol i stupani obrazovanja. Značajnih razlika u primjeni strategija suočavanja i emocionalne regulacije kod odraslih glede dobi gotovo nema. Žene se koriste određenim strategijama ER (npr. preusmjeravanje pažnje) u većoj mjeri nego muškarci, ali između tih dviju skupina nema razlike u primieni strategija suočavanja. Odrasle osobe nižega stupnja obrazovanja češće primjenjuju suočavanje konfrontacijom i odvraćanje pažnje u usporedbi s onima višega stupnja obrazovanja, dok strategiju suočavanja bijeg-izbjegavanje češće rabe odrasle osobe nižega i srednjega stupnja obrazovanja od osoba koje imaju viši stupanj obrazovanja. Sto se tiče ER, odrasle osobe nižega stupnja obrazovanja češće primjenjuju kognitivno preispitivanje važnosti od skupina srednjega i višega stupnja obrazovanja, dok je 
DRUŠ. ISTRAŽ. ZAGREB GOD. 25 (2016), BR. 1, STR. $43-62$

SMRTNIK VITULIĆ, H. \& PROSEN, S

COPING AND.. potiskivanje i uzimanje supstanci kod njih češće samo u usporedbi s odraslim osobama višega stupnja obrazovanja. Korelacije između strategija suočavanja i strategija emocionalne regulacije uglavnom nisu značajne, što upućuje na to da suočavanje i emocionalna regulacija u odrasloj dobi nisu isti procesi.

Ključne riječi: suočavanje, emocionalna regulacija, odrasla dob, spolne razlike, stupanj obrazovanja 